\title{
A Research on the Effect of Treated Grey Water on Workability and Strength of Plainconcrete
}

\author{
Jamuna M, Ramadevi K, Madhumitha P, Gokul Mohandas V, Satheesh T
}

\begin{abstract}
Water from the kitchens, bathrooms, showers, tubs, and washing machines are referred as the grey water. Even though the grey water looks dirty, the treated grey water can be made useful in several beneficial purposes like irrigation and laundry purposes. The aim of this experimental study is to use the treated grey water in concrete making and to analyse its effects on the workability and strength aspects which can be utilized in concrete structures. The waste water samples were collected from the secondary treatment tank located in Kumaraguru College of Technology. The collected samples were analysed for various chemical parameters like $\mathrm{pH}, \mathrm{TSS}, \mathrm{BOD}, \mathrm{COD}$ in the laboratory and tested for their suitability of use in concrete. The setting time of cement, workability, compressive strength have been tested for concrete casted using potable water and for the concrete casted using effluent from grey water treatment. The result from the various test of concrete confirms that the usage of secondary treated grey water in concrete increases both the workability and also the strength of the concrete when compared with the concrete casted using ordinary potable water. Since the treated grey water contains some organic matter in it, it is evident the decomposition of which causes corrosion of concrete if it is meshed with steel bars. The results from the test suggest that the treated grey water can be used only in case of plain cement concrete works.
\end{abstract}

Key Words: Potable water, grey water, workability, compressive strength of concrete

\section{INTRODUCTION}

Water, the most abundant sourcefound to be one of the most essential basic needs in our daily life. It can be used for domestic, agricultural and industrial purposes. In India, the world's population is existing around 17 percent. From which it is contributed about $4 \%$ of world's renewable water resources to people. Apart from domestic, agricultural and industrial use, constructional activities also highly depends on water thus it plays a major role development of construction technology. In civil water has an undeniable use in construction so that it should be available in very large and sufficient quantity. Due to increase in population,rapiddevelopmentofindustries, thereisanincreasing demandforwater. As the water demand increases and to meet the raising demand it is reliable to use left over water from various domestic purpose called as grey water in concrete making. It is highly necessary to promote the recycling of water from various usages. This can be done by using the treated water and

Revised Manuscript Received on 14 August, 2019.

Jamuna M, Assistant Professor, Department of Civil Engineering, Kumaraguru College of Technology, Coimbatore, Tamilnadu, India.

Ramadevi K, Associate Professor, Department of Civil Engineering, Kumaraguru College of Technology, Coimbatore, Tamilnadu, India.

Madhumitha P, PG Scholar, Department of Civil Engineering, Kumaraguru College of Technology, Coimbatore, Tamilnadu, India.

Gokul Mohandas V, PG Scholar, Department of Civil Engineering, Kumaraguru College of Technology, Coimbatore, Tamilnadu, India.

Satheesh T, PG Scholar, Department of Civil Engineering, Kumaraguru College of Technology, Coimbatore, Tamilnadu, India. wastewater for various purposes like agricultural, industrial and variouspurposes.

Concrete is known to be the most widely usable construction material which gives better durabilityforlong time. Oneofthemajoringredientin concrete is water. It is known that about 0.253 gram of water is need for hydration of cement, when we use the hydraulic cement for concretemaking.

Workability of concrete is defined with respect to application of water. Water, also needed for proper curing. The water which is used for concreting should satisfy the basic requirements which are usually mentioned in various Indian codes. The standard codes that are referred specifically is the direct indicator which means that the potable water can be used for concreting but it is not specified in those codes that only potable water has to be used for construction practices. Apart from potable water, the water that is treated can also beused for the construction practices. From the codes, the chemical limits of nonpotablewater also meets the constructions requirement of water. Therefore, in order to promote the environment and to reduce the use of fresh water source, reuse of non-potable water like grey water can be encouraged. Rapid development of industrialization, urbanization and economic growth are paving the way to bridge the gap between the water demand and its supply in various applications. To meet such water demand alternate for fresh water source can be suggested andpreferred.

Grey water is the water which are generated from kitchens, bathrooms, etc. These are left as a waste water or unutilized water. To some extent the grey water with some limit of waste are supposed to be utilized for irrigation purposes. Therefore it is highly essential forconducting certain research works on substituting potable form of water by the recycled form of water in partial or fully. The study was carried out to study the properties of concrete in fresh and hardened concrete prepared by making use of secondary treated water form kitchens etc. This work aims to analyse the workability and compressive strength of concrete.Thetestedresults of this werecomparedwiththeresults obtained from concrete casted with potable water.

\section{NEED FOR THE EXPERIMENTATION}

On considering the increasing demand of potable water for agricultural, industrial and other developmental works, necessary efforts are being made to determine the effectiveness of grey water concreting. Cement is the only ingredient which is mainly responsible as the binding material. Therefore this study is focussed on determining the setting time of cement and workability of concrete. The

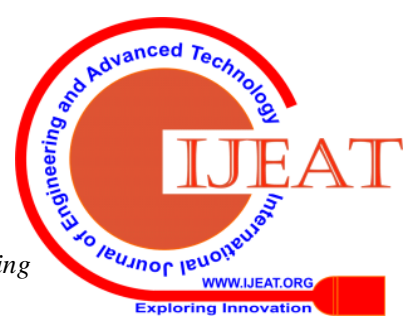


waste water obtained from the effluent of secondary treatment plant were collected and the concentration was predicted using the analytical procedure. The physical and chemical contaminants of grey water namely potential of Hydrogen ion, Totalsuspendedsolids, Total Hardness-to know about the corrosivity nature,Biochemical Oxygen Demand (BOD) andChemical Oxygen Demand (COD)was predicted using standard procedure.Theanalysedsampleswere compared with the code of practice (table 3.1) and suggested to use the treated grey water for above purposes and also in construction industries, by means of which we can save a lot of freshwater and awareness can spread on the importance of water.

\section{QUALITY REQUIREMENTS OF TREATED GREYWATER}

The table 3.1 shows some of the physical and chemical characteristics of treated water that are obtained under necessary laboratory conditions.

Table 3.1 Quality Requirements Of Treated Water For Concreting

\begin{tabular}{|c|c|c|c|}
\hline $\begin{array}{l}\text { PARAMETE } \\
\text { RS }\end{array}$ & $\begin{array}{l}\text { PERMISSIB } \\
\text { LE LIMITS } \\
(\mathrm{mg} / \mathrm{l} \text { except } \\
\text { for } \mathrm{pH})\end{array}$ & \begin{tabular}{|l|} 
TEST \\
VALUES \\
OBTAINED \\
(mg/l except for \\
pH)
\end{tabular} & $\begin{array}{l}\text { REFERENC } \\
\text { ES } \\
\end{array}$ \\
\hline Total solids & 50000 & 1220 & $\begin{array}{l}\text { IS 456, } \\
\text { ASTM } \\
\text { C1602[ 32] }\end{array}$ \\
\hline Total & 2000 & 784 & IS 456 \\
\hline Organic solids & 200 & 720 & IS 456 \\
\hline $\begin{array}{l}\text { Inorganic } \\
\text { solids }\end{array}$ & 3000 & 500 & IS 456 \\
\hline $\mathrm{pH}$ & $\begin{array}{l}\text { Greater than } \\
\text { or equal to } 6\end{array}$ & 7.54 & IS 456 \\
\hline $\begin{array}{l}\text { Total } \\
\text { alkalinity }\end{array}$ & 250 & 3.4 & IS 456 \\
\hline Total acidity & 50 & 1.4 & IS 456 \\
\hline Chlorides & 500 & 562.5 & $\begin{array}{l}\text { IS 456, BS } \\
\text { EN 1008[ 34], } \\
\text { ASTM } \\
\text { C1602 }\end{array}$ \\
\hline Total hardness & $\begin{array}{ll}\text { No } & \text { specific } \\
\text { limit }\end{array}$ & 3.4 & - \\
\hline BOD & 20 & 6.5 & IS 3025 \\
\hline COD & 250 & 46.4 & IS 3025 \\
\hline
\end{tabular}

Here, itisfoundthatthechloridecontentobservedintreatedgrey waterwashigherthanthe permissible limit. The presence of high chloride content in water will thus have the effect on the probability of corroding the steel. Since we are dealing with the plain concrete, the effect of chloride concentration can be neglected but which is to be considered as important case for reinforcedconcrete.

\section{EXPERIMENTAL PROGRAM}

The physio-chemical characteristics of treated grey water has been done and it is noted that the water can be used for plain concreting works. Further experimental analysis were necessarily carried out for verifying the by making use of treated grey water.

\subsection{SETTINGTIME}

\subsubsection{Initial settingtime of cement:}

500 grams of cement was taken and it was made into a fine paste with a required quantity of greywater for performing the first experimental trial. The cement paste was prepared according to the Indian standard. The behavior of the cement paste was determined using vicat'smould apparatus. To start with the vicat'smould was filled with required quantity of cement paste and the needle was lowered gently into it. Then it was brought into the surface of the test block and released quickly. Initially, the needle will be piercing in but with the passage of time the paste losses its plasticity nature. As a result, the needle might have penetrated just only about to a depth of 33-35 mm from the top. The period that elapse between the initial and final is taken as initial setting time.

\subsection{DESIGN MIX}

According to IS 10262: 2012, M20 grade concrete was designed and casted in the laboratory. According to SP- 23, 1982 the mix design has been arrived and it is listed below.

Assume that there will be a good quality controlling with mild exposure.

The ratio of Cement, Fine Aggregate, Coarse aggregate and secondary treated grey water is given as

$=1: 1.53: 2.71$

Ingredients required for concreting per cubic metrewas worked out as:

Cement $=373.3 \mathrm{~kg} / \mathrm{m} 3$

Fine aggregate $=605.8 \mathrm{~kg} / \mathrm{m}^{3}$

Coarse aggregate $=1067.8 \mathrm{~kg} / \mathrm{m}^{3}$

Secondary treated grey water $=197$ litres

\subsection{TEST ON FRESH CONCRETE}

\subsubsection{Slump Test}

Slump test is the matter ofassessing the consistency. It is indirect form which is used to access whether the correct amount of water proportion has been added.The slump cone is firstplaced on a solid, impermeable, levelled surface and then filled with the fresh prepared concrete in three layers in the mould and each layer is tamped properly to get better results. Finally the cone is lifted carefully and the difference in levels was noted to get the slump values. The slump may take 
one of the three defined forms namely true slump wherethe concrete subsides as it is, shear slump where the top portion of the concrete tends to shear off and slips along the sideways and collapse slump wherethe concrete completely collapses.

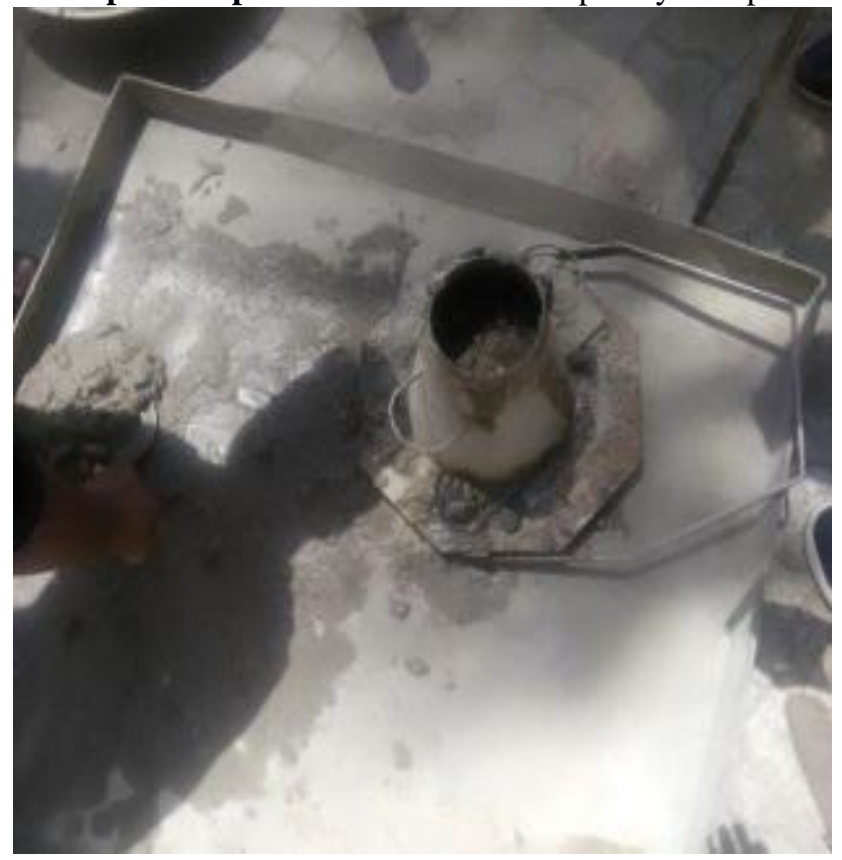

Figure 4.1 Slump Test

\subsection{TEST ON HARDENED CONCRETE}

\subsubsection{Compressive strength Test}

Compressive strength of the concrete is used to access the capacity of the material to withstand the load. Also defined as compressive strength is the one which can resist the compression load, whereas tensile strength is resisting the tension force. The strength of the various materials can be analysed by various strength tests like tensile test, compressive, and shear strength. The behaviour of each materials will differ, some can fracture at theircompressivestrengthlimits; others can deformirreversibly. Compressive strength is considered as important factor in the design of various structures.

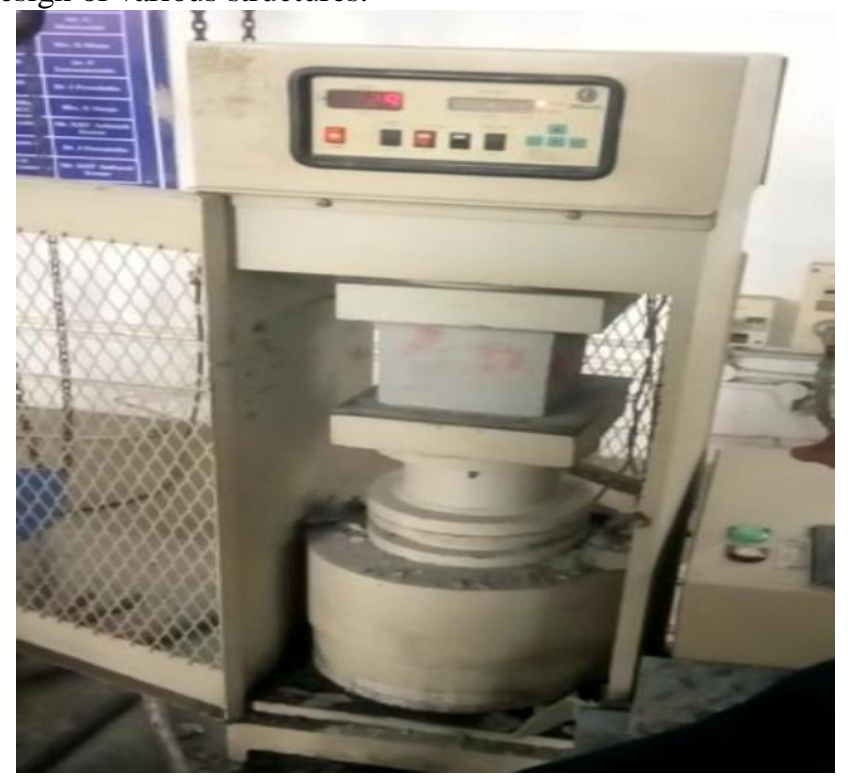

Figure 4.2 Compressive test on concrete

\section{RESULTS AND DISCUSSION}

- Initial setting time was found to be 34 minutes

- $\quad$ Final setting time was found to be540minutes with a slump value of $70 \mathrm{~mm}$

- $\quad$ Degree of workability was found to beMedium

Table 5.1 Compressive strength of concrete

\begin{tabular}{|l|l|l|l|}
\hline $\begin{array}{l}\text { TYPE OF } \\
\text { CONCRETE }\end{array}$ & $\begin{array}{l}\text { 7 days } \\
(\mathbf{M P a})\end{array}$ & $\begin{array}{l}\mathbf{2 8} \text { days } \\
(\mathbf{M P a})\end{array}$ & $\begin{array}{l}\text { CURING } \\
\text { METHOD }\end{array}$ \\
\hline $\begin{array}{l}\text { Concrete made using } \\
\text { potable water }\end{array}$ & 16.62 & 23.15 & $\begin{array}{l}\text { Ordinary Tap } \\
\text { water }\end{array}$ \\
\hline $\begin{array}{l}\text { Concreting done } \\
\text { using treated } \\
\text { greywater }\end{array}$ & 17.11 & 27.55 & $\begin{array}{l}\text { Ordinary Tap } \\
\text { water }\end{array}$ \\
\hline $\begin{array}{l}\text { Concreting done } \\
\text { using treated } \\
\text { greywater }\end{array}$ & 16.6 & 26.5 & Grey water \\
\hline $\begin{array}{l}\text { Concrete made using } \\
\text { treated greywater }\end{array}$ & & 23.79 & Steam curing \\
\hline
\end{tabular}

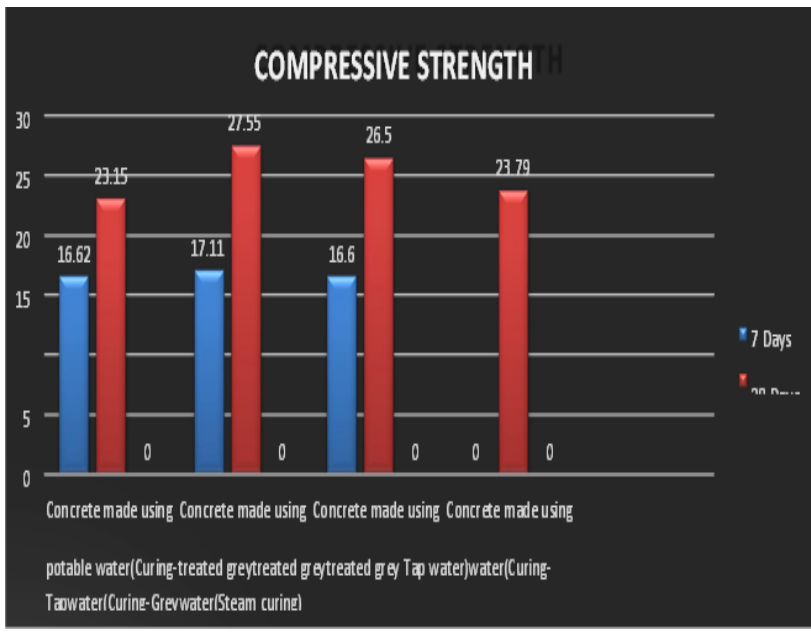

Graph 5.1 compressive strength comparison

Thus, the results have been obtained for setting time, degree of workability and the strength of concrete by use of treated grey water as an alternative. The compressive strength of concrete was foundtyusingdifferenttypesofcuring likesteamcuring, curing intreatedwater.Theinitial form of setting time which is got as 34 minutes and final setting time found as 540 minutes is found to be in optimal range as compared to the general conventional or traditional concrete. The slump value is found to be $70 \mathrm{~mm}$ which gives the mediumrangeofworkabilitysothatcanbeusedbetterwiththecon cretemaking.Then,thecompressive strength was found to be increasing with the use of the secondary treated geywater as compared with the use of ordinary tap water. Hence, for M20 concrete, it can be suggested to use the secondary treated grey water which can improve the compressive strength of concrete.

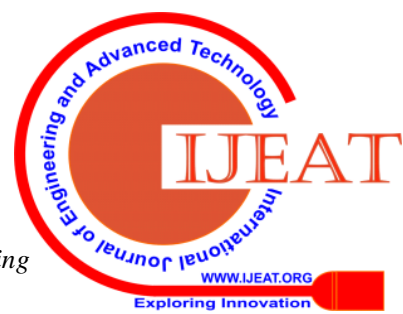




\section{A RESEARCH ON THE EFFECT OF TREATED GREY WATER ON WORKABILITY AND STRENGTH OF PLAINCONCRETE}

\section{CONCLUSION}

Since there is a large and considerable availability of greywater, it has been utilizedin our project to meet the water demand. It was found that Greywater before use should be strictly disinfected so as to avoid the health risks of people who are working with the kind of treated water. From this experiment, it is concluded that the secondary treated grey water which we collected contains minor fraction of contaminants and it was found to be suitable as per IS provision. The setting time of cement paste using greywater was found withintheIndian Standardlimits. Also, thestrengthofconcretewasfoundtobeincreased by using secondary treated water for concreting purposes. The use of different types of curing also has an impact on strength of concrete structure. The strength waschecked at the end of 28 days to get the ultimate strength.Thus by making use of greywater the cost of construction of concrete structures will be reduced considerably in case of plain cement concrete works.

\section{REFERENCES}

1 K.J.Kucche, Dr.S.S.Jamkar, Dr.P.A.Sadgir" Quality of water for making concrete: A review of Literature", International Journal of Scientific and research publications.(2015)

2 Marcia Silva and TarunR.Naik ,"Sustainable use of resources-Recycling of Sewage treatment plant water in concrete", Second international conference on sustainable construction materials and Technologies, (2010)

3 G.L.Low, K.Y.Ng, W.L.Ng, C.T.Tam, R.B.W.Heng, "Use of Recycled cement based slurry water for making concrete", Journal of The Institution of Engineers, Malaysia,(2007)

4 RamkarA.P.,AnsariU.S.“"EffectofTreatedWasteWateronStr engthofConcrete"IOSRJournal of Mechanical and Civil Engineering (IOSR- JMCE) e- ISSN: 2278-1684,p-ISSN: 2320-334X, Volume 13, Issue 6 Ver. II (Nov. Dec.2016),PP 41-45

5 RajeshT.Peche,Dr.SanjayS.Jamkar,Dr.ParagA.Sadgir,“'Infl uenceOfGreyWaterAsMixing Water On Properties And Strength Of Cement", International Journal of Technology Enhancements and Emerging Engineering Research Volume3,Issue 05 ISSN 2347- 4289

6 Abdul Razak.B.H, Dr.D.L.VenkateshBabu, Experimental investigation on usage of greywater in concrete production, International Research Journal of Engineering and Technology, volume-2, Issue- 08,nov2015. 